\title{
MICROTEXTURES AND THE ORIGIN OF MUSCOVITE-KAOLINITE INTERGROWTHS IN SANDSTONES OF THE UTRILLAS FORMATION, BASQUE CANTABRIAN BASIN, SPAIN
}

\author{
Javier Arostegui ${ }^{1}$, María Jesús Irabien ${ }^{1}$, Fernando Nieto ${ }^{2}$, Javier Sangüesa ${ }^{1}$ And \\ María Cruz Zuluaga ${ }^{1}$ \\ 'Departamento de Mineralogía y Petrología, Facultad de Ciencias, Universidad del País Vasco/E.H.U., Apartado 644, \\ 48080 Bilbao, Spain \\ ${ }^{2}$ Departamento de Mineralogía y Petrología, Universidad de Granada, 18002 Granada, Spain
}

\begin{abstract}
Muscovite-kaolinite intergrowths found in Albian sandstones of the Basque Cantabrian basin (northern Spain) were studied by optical, scanning and electron microscopy and electron microprobe analysis. Kaolinitization begins at grain edges, forming the characteristic fanned-out textures, and propagates toward the interior along the cleavages of muscovite. Kaolinite and muscovite occur as thick packets, being free of interlayering. Phase boundaries between both minerals show bidimensional crystallographic continuity, and no intermediate phases have been identified. The data obtained suggest that muscovite only supplied a template suitable for the epitactic crystallization of kaolinite, while Al was available in sufficient amounts due to the dissolution of detrital K-feldspar. Very small packets of magnetite or maghemite showing a coherent orientation with the kaolinite crystals have been recognized, and could be responsible for the small Fe contents usually detected in electron microprobe analyses of kaolinite.

Textural relationships between authigenic kaolinite and deformation microstructures in the intergrowths, combined with previous information about burial conditions, show that alteration proceeded during a late stage of the diagenetic history, related to the uplift of the studied materials as a result of the Alpine orogeny.
\end{abstract}

Key Words-Epitactic, Geomechanical Parameters, HRTEM, Muscovite-kaolinite Intergrowth, SEM, Timing.

\section{INTRODUCTION}

Muscovite-kaolinite intergrowths occur under a range of environmental conditions: weathering of soils (Banfield and Eggleton, 1990; Singh and Gilkes, 1991; Jeong, 1998), hydrothermal alteration (Craw et al., 1982; Jiang and Peacor, 1991) and different stages of diagenesis, e.g. early (Crowley, 1991) and advanced diagenesis, (Marfil and Gomez Gras, 1992) and subsequent uplift (Jiang et al., 1994). For the intergrowth to be formed, muscovite must provide template sites for the nucleation and subsequent growth of authigenic kaolinite, while additional elements must be supplied by a parent material (muscovite and/or other minerals such as feldspars and other phyllosilicates). Previous works have reported that kaolinitization may proceed, when muscovite is the parent mineral, via epitaxial or topotaxial mechanisms, and 'remains' of the transformation can frequently be recognized. Transmission/analytical electron microscopy (TEM/AEM) observations allowed some authors (Banfield and Eggleton, 1990; Jiang and Peacor, 1991) to identify, within the intergrowth of randomly interstratified illite-smectite, smectite and smectite-like layers, which may have served as transitional phases between muscovite and kaolinite. Singh and Gilkes (1991), on the contrary, found no evidence of intermediate compounds. On the basis of the chemical information obtained by AEM and electron probe micro-analysis (EPMA), they concluded that alteration involved preservation of some components of the parent muscovite, which had resulted in the retention of some elements $(\mathrm{Cr}$ and $\mathrm{Fe})$ in authigenic kaolinite.

During a diagenetic study of the sandstones from the Utrillas Formation (Basque Cantabrian basin, Spain), based on the clay mineralogy, it was found that detrital grains of muscovite were frequently altered to kaolinite, typically displaying fanning-out textures. It is well known that authigenesis of kaolinite has important implications, giving information about the physical-chemical conditions in the deposit (Bjørlykke, 1998) and the stage of diagenetic evolution (Kübler, 1984). This study focused on the muscovite-kaolinite intergrowth, which was examined using optical microscopy, scanning electron microscopy (SEM, BSE), high-resolution TEM (HRTEM), AEM and EPMA in order to obtain datailed textural and chemical information. The main aims of this work were to determine the morphology and composition of the intergrowth (occurrence/absence of intermediate phases, crystallographic relationships between both minerals) and to elucidate its origin (mechanism of formation and timing of modification). The integrated approach including chemical, textural, microstructural and geomechanical data has proved to be very useful 


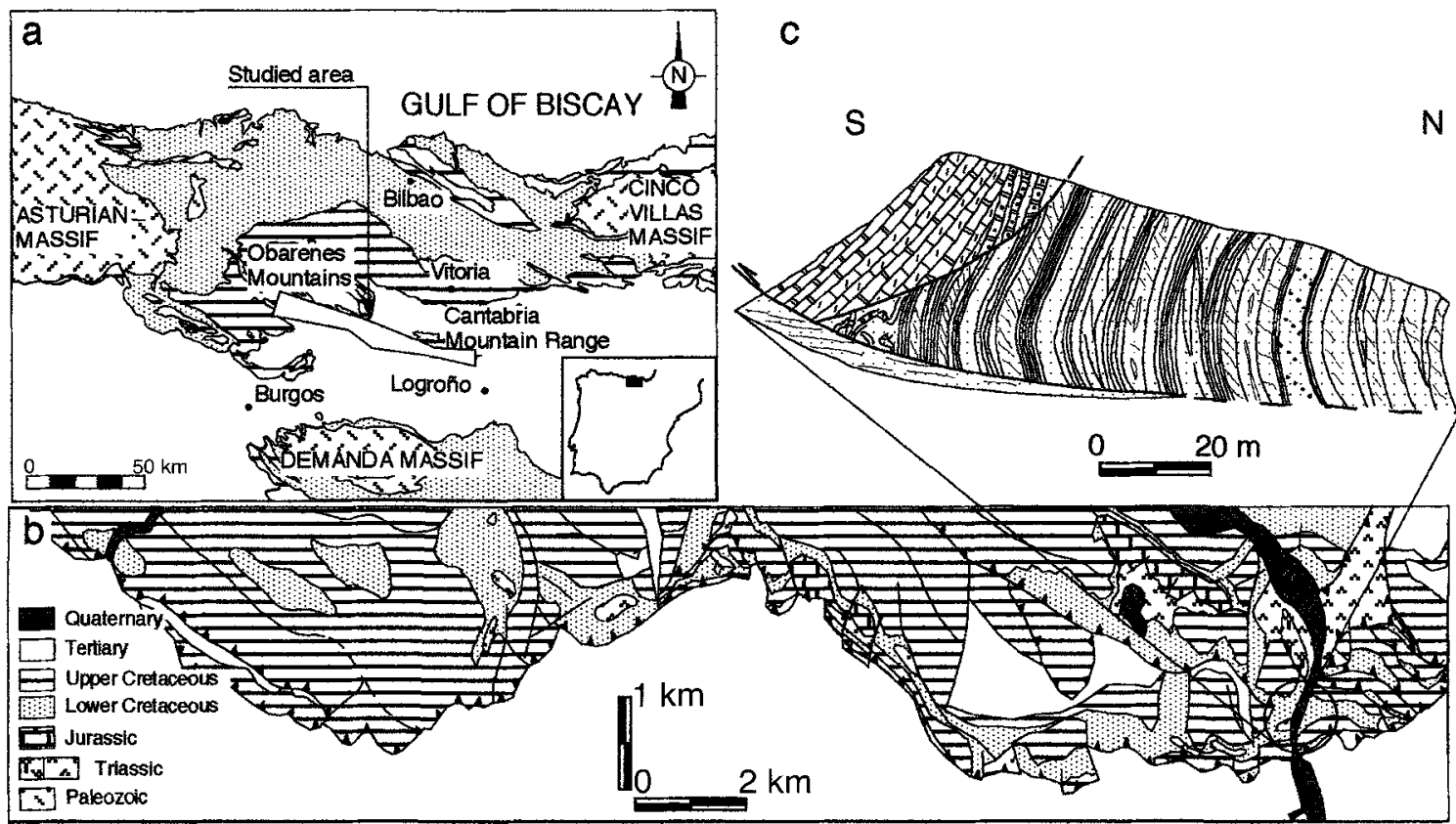

Figure 1. (a) Geographical and geological setting of the studied area. (b) Detailed geological map. (c) Schematic tectonic interpretation of one of the outcrops.

in studies of diagenetic concern, allowing us to determine the kaolinitization mechanism and temporal relationships between alteration, diagenesis and tectonic events in the surrounding area.

\section{GEOLOGICAL SETTING}

The studied area is located in the southern border of the Basque Cantabrian basin (Figure 1), between the Pyrenean and the Asturian massifs (Iberian Peninsula). Its depositional history, from the Permo-Triassic to the present day (Rat, 1988), was mainly controlled by the opening and closure of the Bay of Biscay (Central Atlantic Ocean). Although considerable amounts of sediment $(>6000 \mathrm{~m}$ ) were deposited in the central area of the basin, the southern border is characterized by Jurassic and Cretaceous sediments and low sedimentation and subsidence rates. Folding and uplift during the Alpine orogeny resulted in the formation of regional thrust structures.

The Utrillas Formation (Albian age) is composed mainly of sandstones interpreted as braided river channel-fills and interchannel subaerial and flood-basin deposits. Recent data from subsidence and thermal modeling (Sangüesa and Arostegui, 2000) suggested a maximum burial depth of $\sim 700 \mathrm{~m}$ for this Formation in the border of the basin. Those authors calculated, starting from the measured values of vitrinite reflectance $(\operatorname{Rr}=0.34 \%)$, maximum temperatures as high as $50-55^{\circ} \mathrm{C}$

\section{EXPERIMENTAL}

\section{Materials}

Kaolinite was found in fresh rock samples of the sandstones collected from three outcropping series of the Utrillas Formation. The formation consists of scarcely cemented sandstones, arenites and lithic graywackes with intercalations of conglomerates and lutites. Monocrystalline and polycrystalline quartz with shared metamorphic texture, K-feldspars and mica are the main constituents of the framework of the sandstones examined. Very scarce grains of plagioclase were found in only a few samples. The matrix, when it exists, comprises microcrystalline quartz and clay minerals. Kaolinite, which is the main component of the cement, occurs in the pore-space or as intergrown with muscovite. Primary porosity can be recognized. A more detailed description of facies and mineralogy is reported in Zuluaga et al. (1998).

\section{Methods}

Sixty uncovered thin-sections were examined using optical microscopy. Samples selected for SEM investigation were examined using a JEOL JSM-6400 scanning electron microscope in back-scattered electron (BSE) mode. Quantitative chemical analysis was carried out using a CAMEBAX SX-50 electron probe microanalyzer operated at $15 \mathrm{kV}$ using an electron beam current of $10 \mathrm{~mA}$ and a $5 \mu \mathrm{m}$ beam diameter.

Fresh surfaces of rock fragments were mounted on stubs, coated with either carbon or gold and examined 
in secondary electron (SE) mode using the instrument above operated at $20 \mathrm{kV}$ and a current of $10^{-10} \mathrm{~A}$. An energy-dispersive $\mathrm{X}$-ray spectroscopy system (EDX system Link) provided qualitative elemental analyses, useful for distinguishing clay minerals, K-feldspars and plagioclase.

Samples for TEM analysis were selected using a petrographic microscope on uncovered thin-sections, perpendicular to the bedding and to the $(001)$ plane of the detrital phyllosilicates; the sections were glued onto $\mathrm{Cu}$ rings and then thinned by an argon ion Gatan Dual mill 600 at the Centro de Instrumentación Cientifica (CIC) of Granada University. Two sets of ionmilling conditions were used: (1) $6 \mathrm{kV}, 1 \mathrm{~A}$ and $15^{\circ}$ incident angle while perforating; and (2) $6 \mathrm{kV}$, lowangle $\left(12^{\circ}\right)$ and low-current $(0.4 \mathrm{~A})$ final milling for $\sim 1 \mathrm{~h}$ to clean the sample surface. The samples were analysed using a Philips CM20 scanning transmission electron microscope (STEM) equipped with an EDAX solid-state EDX detector, operating at $200 \mathrm{kV}$, with a $\mathrm{LaB}_{6}$ filament, and a point-to-point resolution of $2.7 \AA$ (CIC, Granada University). Electron diffraction patterns were obtained from selected areas (SAED); lattice-fringe images (HRTEM) were obtained following the procedures suggested by Buseck et al. (1988) and Buseck (1992). Areas for phyllosilicate analysis were selected carefully on lattice-fringe images to control the textural position and verify the absence of contamination by other phases. Quantitative analyses (AEM) were obtained only from thin edges, using a $50 \AA$ beam diameter and a $100 \times 20 \mathrm{~nm}$ scanning area, with the long axis oriented parallel to the phyllosilicate packets. The samples were tilted $20^{\circ}$ towards the detector. Albite, biotite, spessartine, muscovite, olivine, titanite, $\mathrm{MnS}$ and $\mathrm{CaS}$ were used to obtain $\mathrm{K}$ factors for the transformation of intensity ratios to concentration ratios following the procedures of Cliff and Lorimer (1975) and Champness et al. (1981).

\section{RESULTS}

\section{Occurrence of kaolinite}

Optical and electron microscopy observations showed that kaolinite occurs in three distinct modes. The first consists of broken subhedral and pseudo-hexagonal flakes $(\sim 10 \mu \mathrm{m})$ of kaolinite, which exhibit irregular edges under SEM (Figure 2a), consistent with a detrital origin. These grains, which appear as a component of the sandstones, are frequently associated with detrital muscovite (Figure 2b). Although both minerals exhibit a similar morphology, they can be distinguished using EDX analysis (Figures 2a, b).

The second mode of kaolinite occurs as vermicular booklets composed of pseudo-hexagonal plates of $\sim 5-$ $10 \mu \mathrm{m}$ in diameter (Figure 3). These aggregates, up to $30-40 \mu \mathrm{m}$ thick along the $c$ axis, seem to expand into and fill the primary porosity of sandstones.
The third mode is as booklets of authigenic kaolinite grown between cleavage sheets of pre-existing detrital mica (Figure 4). These packets of muscovite are frequently folded (Figure 4a, c), slided (Figure 4a, b) or even broken (Figure 4d). Growth of kaolinite starts at grain edges, giving the characteristic fanned-out textures (Figure $4 \mathrm{e}, \mathrm{f}$ ). This process propagates toward the interior, and can involve the complete disarticulation of the original grain of muscovite (Figure 4c). Furthermore, deformed packets seem to adapt the adjacent pores and eventually to fill them up (Figure 4c). However, kaolinitization may also generate new empty spaces (Figure 4e). Optical and electron microscope observations reveal that, in most grains showing intergrowths, the displaced sheets of muscovite can be traced back to the parent mica without any observable loss in volume (Figure 4c). However, in some cases the continuity of the thin packets of muscovite is more diffuse, and they seem to disappear into a kaolinitic matrix (Figure 4f).

\section{Chemistry of kaolinite and muscovite}

Chemical data obtained by microprobe analysis of detrital muscovite (M1), pore-filling kaolinite (K1) and muscovite (M2) and kaolinite ( $\mathrm{K} 2$ and $\mathrm{K} 3$ ) from the intergrowths are reported in Table 1 . The representative structural formulae for $\mathrm{M} 1$ and $\mathrm{M} 2$ are almost identical. The number of ${ }^{1 \mathrm{~V}} \mathrm{Al}$ is 0.89 and the number of ${ }^{\mathrm{V}} \mathrm{Al}$ is 1.8. Furthermore, the number of interlayer cations $\left(\mathrm{K}^{+}\right.$and $\left.\mathrm{Na}^{+}\right)$is near 1 . Such a composition is typical of muscovite with a near end-member composition.

Both modes of authigenic kaolinite were analyzed and the structural formulae were calculated (Table 1). Sample K1 (pore-filling kaolinite) shows an Al/Si ratio of 0.95 . The slight enrichment in $\mathrm{Si}$ (4.07) with respect to the expected value for ideal kaolinite $(4.00)$ can be attributed to the existence of impurities, under the EMPA resolution, between packets of kaolinite. The octahedral occupancy is clearly depleted (3.87) and the interlayer occupancy is by far the lowest $(0.03)$.

The analysis of the kaolinites from the fanned-out edges ( $\mathrm{K} 2$ and $\mathrm{K} 3$ ) gives $\mathrm{Al} / \mathrm{Si}$ ratios significantly $<1$ $(0.91$ and 0.89$)$ and greater interlayer occupancy $(0.19$ and 0.58). The compositional data for $\mathrm{K} 2$ and $\mathrm{K} 3$ do not correspond to ideal kaolinite, and the presence of interlayer cations indicates the occurrence of a mixture of kaolinite and muscovite packets in the areas analyzed. This confirms that the resolution of the EPMA and SEM techniques is not sufficient to allow detailed study of the muscovite-kaolinite transitions, because of the complex intergrowth and the beam size of the EPMA equipment.

\section{Transmission electron microscopy}

Low-magnification TEM images (Figure 5) show the same kind of texture previously described in BSE 

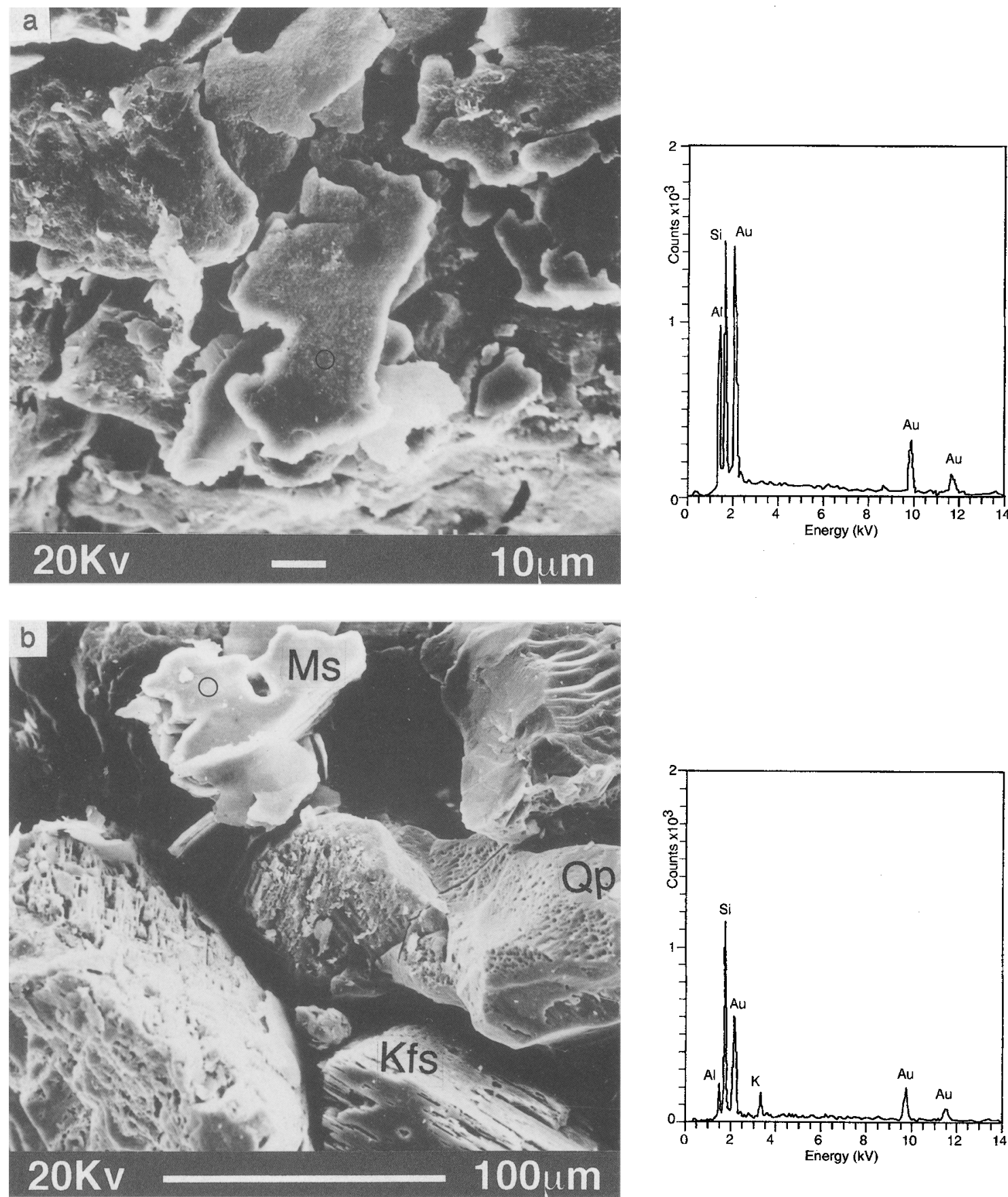

Figure 2. SEM images of microtextures in Albian sandstones. (a) Pseudohexagonal plates of kaolinite and EDX spectra. (b) Detrital grains of K-feldspar (Kfs), polycrystalline quartz (Qp) and muscovite (Ms). EDX spectra of muscovite.

images. Mica and kaolinite form distinct parallel packets, whose size is very variable from the micron scale to those only resolvable in high-resolution images (Figures 6a, b).

Electron diffraction patterns of areas in which mica or kaolinite packets are sufficiently large to permit a single-crystal diagram to be obtained have revealed mica as a two-layer polytype dioctahedral structure; kaolinite in turn is a triclinic one-layer polytype (Figure 7a). Therefore, the presence of dickite and/or nacrite can be ruled out. A variable degree of disorder may be recognized for spots with $k \neq 3 n$, which in some cases produces an almost continuous line for these rows. 


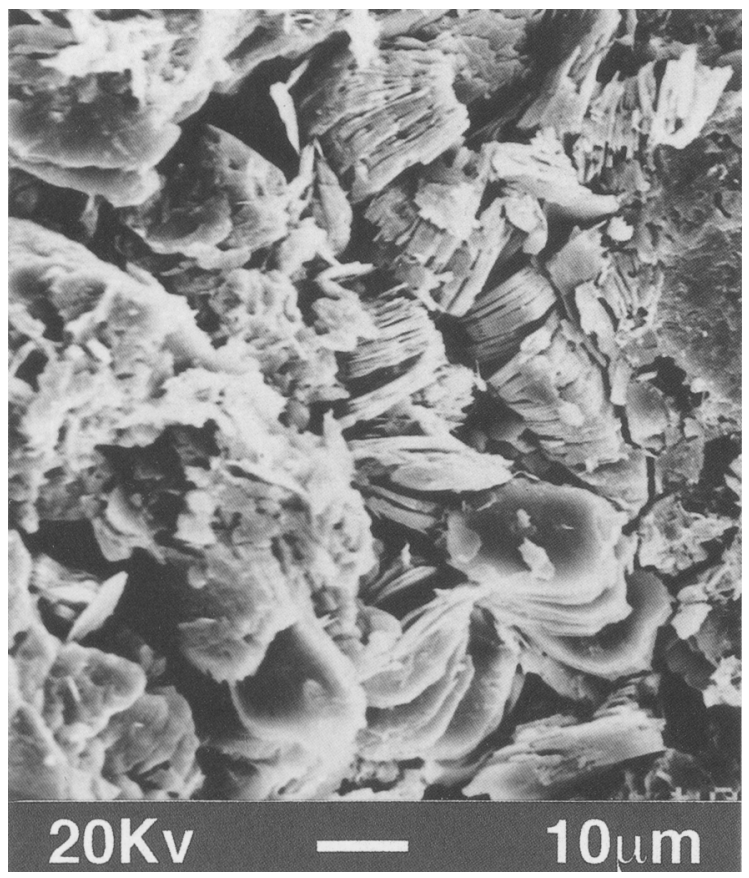

Figure 3. Aggregates of authigenic kaolinite within primary pores of the Utrillas sandstones.

In most cases both the lattices of kaolinite and mica may be recognized in the patterns (Figure $7 \mathrm{~b}$ ). In all the diffraction photographs, crystallographic axes of both phyllosilicates are parallel each other: $\mathrm{c}^{*}$ of kaolinite is parallel to $\mathbf{c}^{*}$ of dioctahedral mica and $\mathbf{b}^{*}$ (or the equivalent direction) of kaolinite is parallel to $\mathbf{b}^{*}$ (or the equivalent direction) of mica.

Lattice-fringe images show wide areas of defectfree straight packets of 10 or $7 \AA$ layers. Kaolinite packets may maintain lattice-fringe resolution over $>2000 \AA$ and completely defect-free packets of more than 20 layers are usual. Fringes of both minerals are always parallel to each other and to their boundaries (Figure 6a). When the edge of the particle is slightly curved, mica layers maintain a perfect parallelism with it, while kaolinite layers are straight and compensate the curvature by means of an extra layer (arrow in Figure 6b). No $7 \AA$ layers within the $10 \AA$ packets, or vice versa, have been recognized.

Bidimensional resolution is precluded by the rapid electron beam damage of kaolinite, which may be particularly concentrated at structural defects or local heterogeneity in composition or structure (Ma and Eggleton, 1999). In the few cases in which $\mathbf{b}^{*}$ (or equivalent direction) periodicity may be recognized for both phyllosilicates, they show crystallographic continuity (Figure 8). As far as we know, images confirming the two-dimensional continuity between muscovite and authigenic kaolinite in the intergrowths have not previously been reported.
Table 2 shows the representative structural formulae of mica (M3 and M4) and kaolinite (K4 and K5) obtained in areas of the intergrowths in which the size of the packets was big enough to allow contaminationfree analyses by AEM to be obtained. Analytical data of M3 and M4 represent a near end-member muscovite, which is very similar in composition, within the error limits of the method, to those analyzed by EMPA in larger-size packets. Chemical data determined for K4 and K5 are coherent with theoretical values for pure kaolinite.

Within the kaolinite areas, very small packets (200$400 \AA$ ) which contain only Fe and O, as identified by means of AEM, are common (Figure 9a). A careful selection of the area for electron diffraction has allowed recognition of the lattice of the oxide mineral superimposed on that of the phyllosilicates (Figure 9 b). The parameters identified, 8.6 and $5.9 \AA$ with absences for $h+k \neq 2 n$, are consistent with the plane normal to $(110)$ of the magnetite lattice. Figure $9 b$ shows a perfect parallelism between phyllosilicates and magnetite crystallographic directions; $\mathbf{b}^{*}$ of phyllosilicates would be coincident with (100) of magnetite and $\mathbf{c}^{*}$ of clay minerals with (110) of Fe oxide. Nevertheless, an alternative interpretation of the oxide lattice is also possible. Because the maghemite unitcell is equivalent, to a triple unit-cell of magnetite, i.e. $\mathbf{a}_{\text {magnetite }}=\mathbf{a}_{\text {maghenite }}$ and $\mathbf{c}_{\text {maghemite }}=3 \mathbf{c}_{\text {magnetite, the plane }}$ normal to (301) of maghemite would, in practice, be indistinguishable from that normal to (101) of magnetite. This is a consequence of the common distribution of anions for both structures with their only difference being the occupancy of some octahedral positions by $\mathrm{Fe}^{2+}$.

\section{DISCUSSION AND CONCLUSIONS}

\section{Origin of kaolinite}

The delicate fabrics of the pore-filling vermicular booklets of kaolinite and the muscovite-kaolinite intergrowth found in the sandstones from the Utrillas Formation suggest an in situ origin, because it is unlikely they would survive sediment transport. As mentioned above, quartz, K-feldspar and muscovite are the main constituents of the sandstones, with very small amounts of plagioclase being present. Thus, Al-containing phases such as $\mathrm{K}$-feldspar and/or muscovite are suggested to be the main potential sources of components for the formation of the authigenic kaolinite. In this respect, it is worth mentioning that detrital grains of K-feldspar showed clear evidence of alteration under SEM, while grains of muscovite appeared to be unaltered. This may be related to the high dissolution rate constant of the $\mathrm{K}$-feldspar, one order of magnitude greater than that for muscovite. These data indicate that the $\mathrm{Al}$ and Si required for the process of kaolinitization to develop is basically supplied by the alter- 

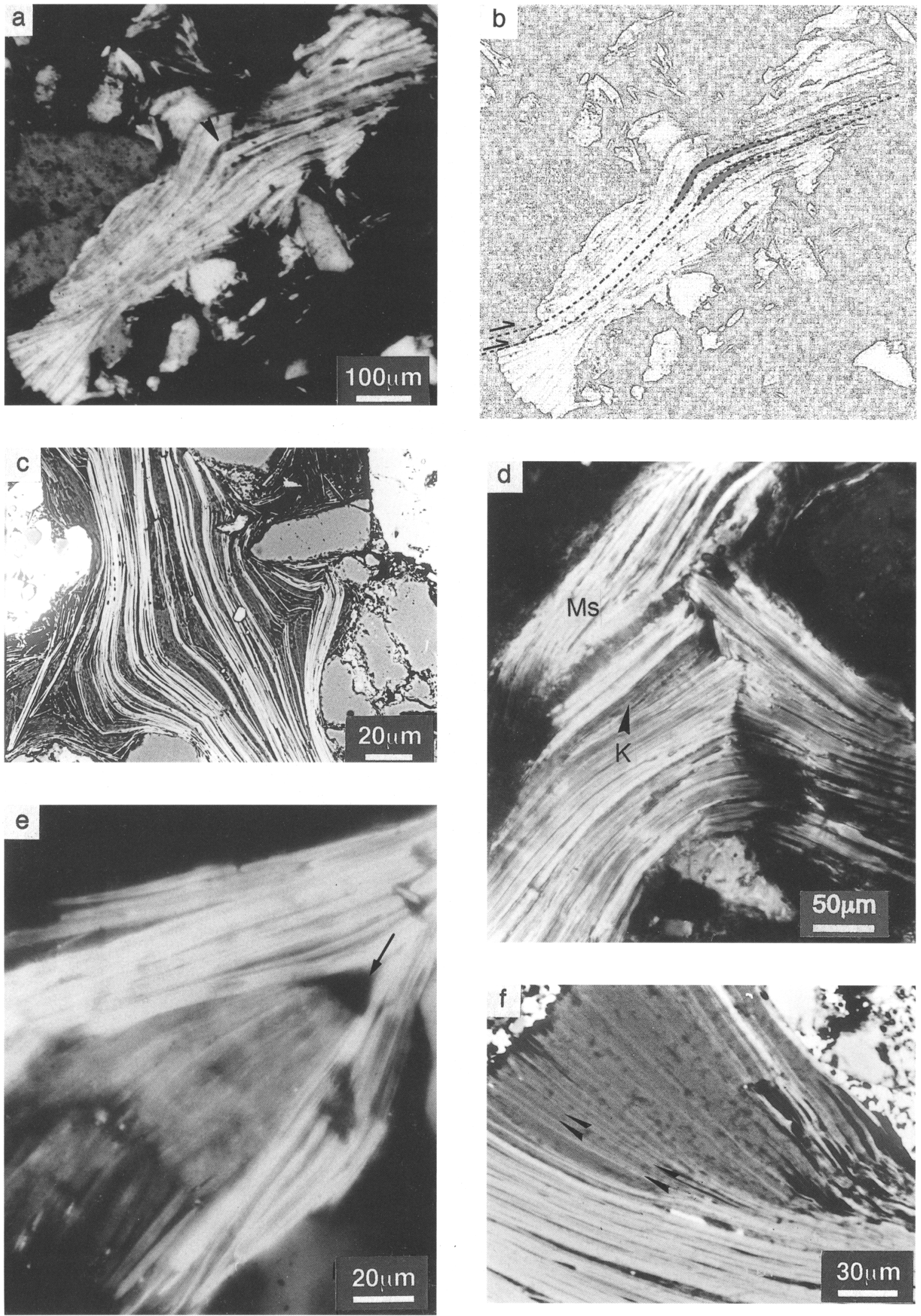
Table 1. Representative electron microprobe analyses (wt.\%, mean of 3 analyses) and structural formulae of muscovite, authigenic kaolinite and detrital K-feldspars. M1: unaltered detrital muscovite; M2: muscovite from a muscovite/kaolinite intergrowth (Figure 4a). K1: booklet of kaolinite (similar to that represented in Figure 3); K2 and K3: fanned-out edges of muscovite/kaolinite intergrowths (Figure 4e, f). Kfs: detrital K-feldspars.

\begin{tabular}{|c|c|c|c|c|c|c|}
\hline & $\mathrm{Ml}^{\prime}$ & M2 & $\mathbf{K} 1^{2}$ & $\mathrm{~K} 2^{2}$ & $\mathrm{~K} 3^{2}$ & $\mathrm{Kfs}^{3}$ \\
\hline $\mathrm{SiO}_{2}$ & 46.15 & 46.30 & 46.93 & 49.14 & 48.60 & 63.04 \\
\hline $\mathrm{TiO}_{2}$ & 0.66 & 0.63 & 0.04 & 0.09 & 0.11 & 0.00 \\
\hline $\mathrm{Al}_{2} \mathrm{O}_{3}$ & 33.85 & 34.32 & 37.93 & 38.14 & 36.61 & 18.39 \\
\hline $\mathrm{FeO}$ & 1.73 & 1.42 & 0.16 & 0.42 & 0.78 & 0.00 \\
\hline $\mathrm{MnO}$ & 0.03 & 0.03 & 0.03 & 0.00 & 0.03 & 0.00 \\
\hline $\mathrm{MgO}$ & 0.70 & 0.61 & 0.10 & 0.15 & 0.43 & 0.01 \\
\hline $\mathrm{CaO}$ & 0.03 & 0.01 & 0.11 & 0.05 & 0.00 & 0.00 \\
\hline $\mathrm{Na}_{2} \mathrm{O}$ & 0.62 & 0.67 & 0.06 & 0.21 & 0.19 & 0.89 \\
\hline $\mathrm{K}_{2} \mathrm{O}$ & 10.67 & 10.30 & 0.12 & 1.52 & 5.40 & 16.11 \\
\hline $\mathrm{Cr}_{2} \mathrm{O}_{3}$ & 0.00 & 0.03 & 0.00 & 0.00 & 0.00 & 0.00 \\
\hline $\mathrm{NiO}$ & 0.00 & 0.03 & 0.07 & 0.07 & 0.00 & 0.00 \\
\hline Total & 94.44 & 94.38 & 85.55 & 89.79 & 92.14 & 98.44 \\
\hline $\mathrm{Si}$ & 3.11 & 3.11 & 4.07 & 4.10 & 4.07 & 2.97 \\
\hline${ }^{\mathrm{IV}} \mathrm{Al}$ & 0.89 & 0.89 & 0.00 & 0.00 & 0.00 & 1.02 \\
\hline${ }^{\mathrm{VI}} \mathrm{Al}$ & 1.80 & 1.83 & 3.87 & 3.75 & 3.62 & - \\
\hline $\mathrm{Ti}^{4+}$ & 0.03 & 0.03 & 0.00 & 0.01 & 0.01 & 0.00 \\
\hline $\mathrm{Mg}^{2+}$ & 0.07 & 0.06 & 0.01 & 0.02 & 0.05 & 0.00 \\
\hline $\mathrm{Fe}^{2+}$ & 0.10 & 0.08 & 0.01 & 0.03 & 0.05 & 0.00 \\
\hline $\mathrm{Na}^{+}$ & 0.08 & 0.09 & 0.01 & 0.03 & 0.03 & 0.08 \\
\hline $\mathrm{K}^{+}$ & 0.92 & 0.88 & 0.01 & 0.16 & 0.58 & 0.97 \\
\hline $\mathrm{Ca}^{2+}$ & 0.00 & 0.00 & 0.01 & 0.00 & 0.00 & 0.00 \\
\hline
\end{tabular}

${ }^{1}$ Normalization is based on total anionic charge of 22.

${ }^{2}$ Normalization is based on total anionic charge of 28 .

${ }^{3}$ Normalization is based on total anionic charge of 16 .

ation of K-feldspar. The following reaction scheme via weathering of feldspars is proposed, using the structural formulae calculated for K-feldspar (EPMA) and kaolinite (AEM):

$$
\begin{aligned}
1 \mathrm{~K}_{0.97} & \mathrm{Na}_{0.08} \mathrm{Al}_{1.02} \mathrm{Si}_{2.97} \mathrm{O}_{8}+0.48 \mathrm{H}_{2} \mathrm{O}+1.04 \mathrm{H}^{+} \\
\rightarrow & 0.25 \mathrm{Al}_{411} \mathrm{Fe}_{0.02} \mathrm{Si}_{3,90} \mathrm{O}_{10}(\mathrm{OH})_{8}+1.99 \mathrm{SiO}_{2} \\
& +0.97 \mathrm{~K}^{+}+0.08 \mathrm{Na}^{+}
\end{aligned}
$$

This reaction requires the supply of $\mathrm{H}^{+}$or $\mathrm{H}_{3} \mathrm{O}^{+}$and the continuous circulation of pore-waters, which facilitate the removal of the alkalis $\left(\mathrm{K}^{+}\right.$and $\left.\mathrm{Na}^{+}\right)$and support a low $a \mathrm{~K}^{+} / a \mathrm{H}^{+}$ratio. During the burial history of Utrillas sandstones, only meteoric waters (Bjorlykke, 1998) could provide the water flux and the protons (via reaction with $\mathrm{CO}_{2}$ ) needed for the precipitation of authigenic kaolinite.

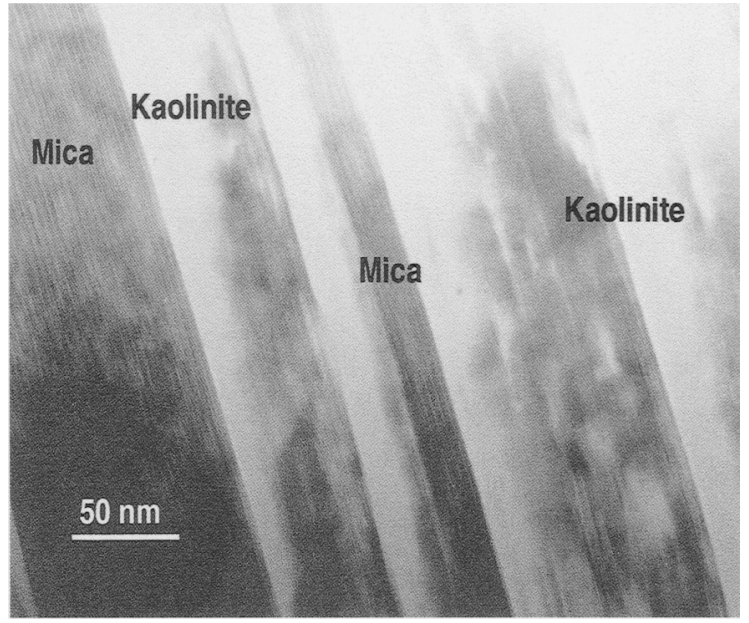

Figure 5. Representative low-magnification TEM image of the mica/kaolinite intergrowths.

Detailed study of the boundaries between muscovite and kaolinite in the intergrowth provided the information required to assess the contribution of the former mineral to the authigenesis of the latter. On one hand, SEM observations showed that the growth of kaolinite between the cleavage layers of mica resulted in a net increase of volume of the altered grain. The apparent thickness of the packets of muscovite seemed to be fairly constant, even in most cases of extreme diagenetic modification.

On the other hand, lattice-fringe images of the intergrowth showed thick packets of muscovite and kaolinite free of interlayering. Moreover, the muscovite layer exhibited a perfect continuity along the muscovite/kaolinite boundaries, and no amorphous and/or intermediate aluminosilicate compounds were observed separating the minerals (Figures 6 and 8). The AEM data confirmed that the intergrowths consist solely of a two-phase mixing between pure muscovite and pure kaolinite, ruling out a progressive mechanism of alteration through different phases, as has been proposed by some authors (Bjorlykke et al., 1979; Banfield and Eggleton, 1990). Furthermore, they also rule out a topotactic origin for kaolinite, because it should involve to some extent the prior dissolution of the mica and possibly a lack of continuity in the packets of muscovite (Robertson and Eggleton, 1991; Singh and Gilkes, 1991). Kaolinite seems to grow epitaxially from

$\leftarrow$

Figure 4. Microtextures in muscovite-kaolinite intergrowths (dark zones: kaolinite; light zones: muscovite). (a) Optical photomicrograph of a deformed kaolinite-muscovite intergrowth and microstructural interpretation of the deformation features (b). (c) BSE image of a deformed intergrowth which collapses the adjacent primary pores. Note the continuity of the packets of mica. (d) Broken grain of detrital muscovite and subsequent kaolinitization. (e) Growth of a booklet of kaolinite in a fanned-out edge of an intergrowth. This generates an empty space (arrow). (f) BSE image of a fanned-out edge. Note the apparently diffuse continuity of the mica packets. 

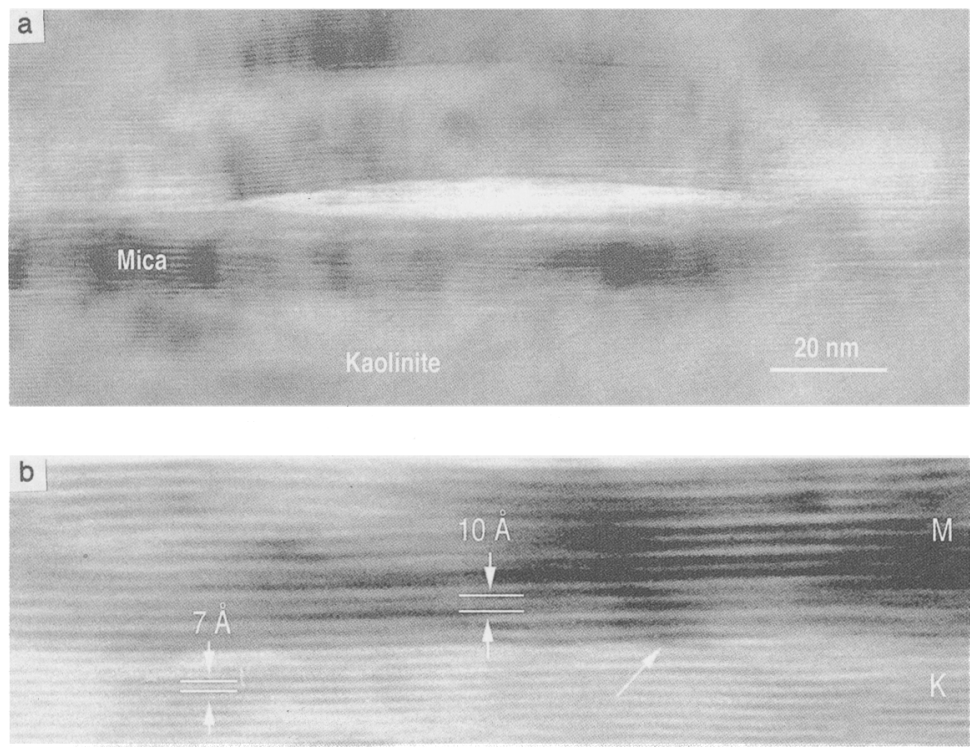

Figure 6. Lattice fringe images of the mica/kaolinite boundaries in the intergrowths. (a) Small packets of mica ( $\sim 10$ nm wide) between two kaolinite areas. (b) Fringes of both minerals are parallel each other and to their boundaries. Kaolinite layers are straight and compensate the slight curvature of the mica crystal by means of an extra layer (white arrow).

solution onto the surfaces of muscovite layers. Electron diffraction patterns of coexisting kaolinite and muscovite showed coherent orientation of lattices of both phyllosilicates (Figure $7 \mathrm{~b}$ ). Bidimensional resolution obtained in Figure 8 proved coherent phase boundaries, related to the similar dimensions of (001) in both minerals (Bailey, 1980). Therefore, detrital muscovite acted only as host material, providing the templates for the nucleation and growth of authigenic kaolinite.

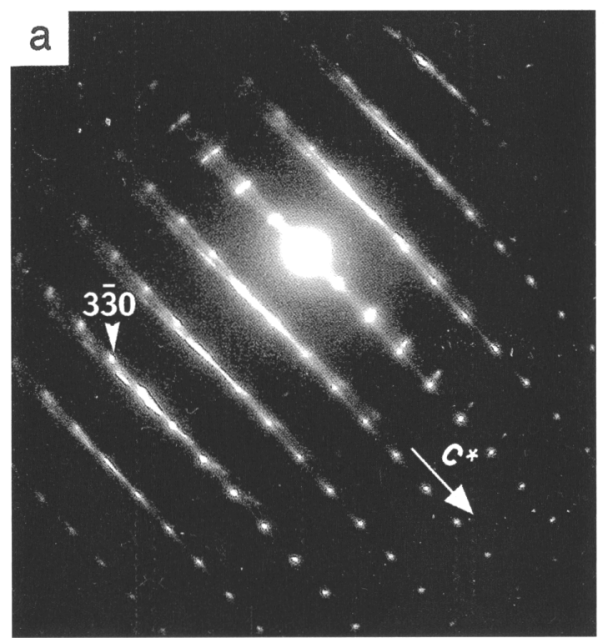

The formation of small packets of Fe oxides (magnetite or maghemite) within the kaolinite (Figure 9a) appears to have resulted from the precipitation of the excess $\mathrm{Fe}$ in solution, which can not be incorporated into the kaolinite structure. The AEM data from the kaolinite areas of the intergrowths, represented in Table 2, show Fe contents somewhat lower than those reported using EPMA (Table 1). This slight difference can be attributed to the lower resolution of EPMA, reflecting the effects of two-phase intermixing be-

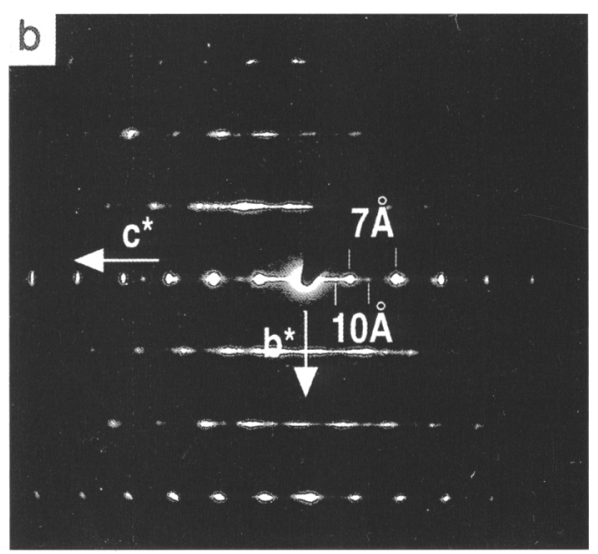

Figure 7. (a) [110] electron diffraction pattern of a kaolinite area. (b) Electron diffraction pattern of an intergrowth. b* represents all the three equivalent directions due to the hexagonal symmetry of the (001) planes of phyllosilicates. 


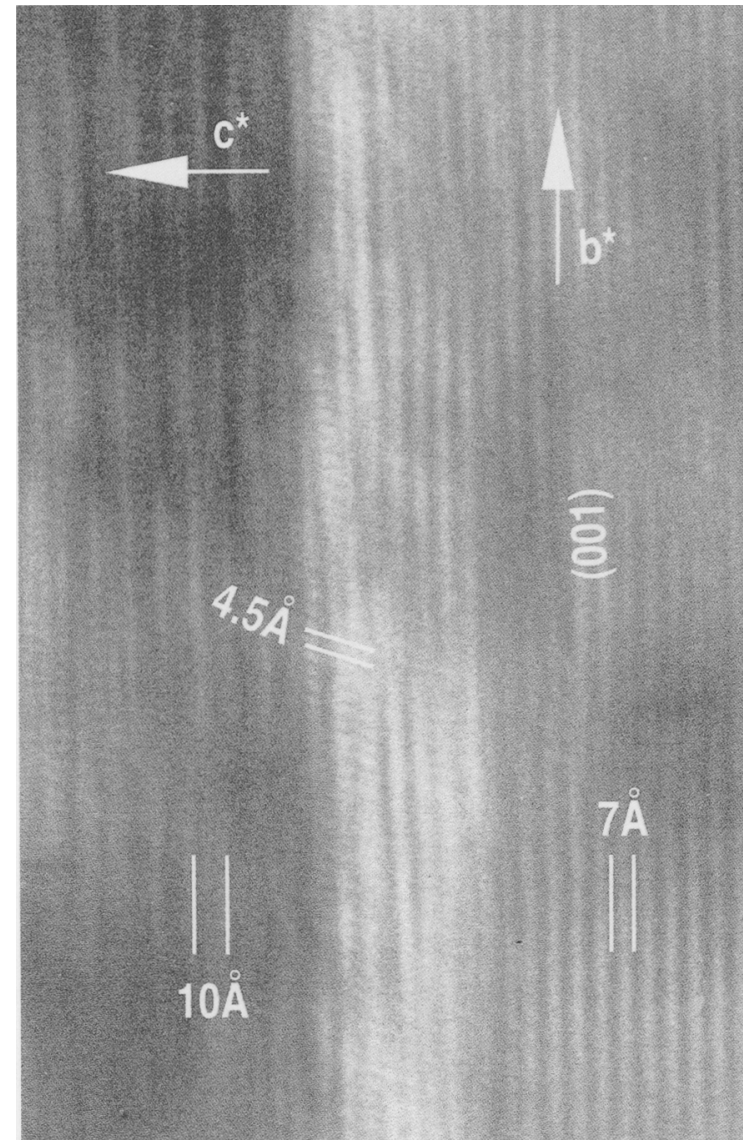

Figure 8. Crystallographic coherency between mica and kaolinite in a boundary with bidimensional resolution.
Table 2. Structural formulae derived from AEM analyses of muscovites (M3 and M4) and authigenic kaolinites (K4 and $\mathrm{K} 5$ ) in edges of muscovite/kaolinite intergrowths.

\begin{tabular}{lcccc}
\hline & $\mathrm{M}^{1}$ & $\mathrm{M}^{1}$ & $\mathrm{~K}^{1}$ & $\mathrm{K5}^{2}$ \\
\hline $\mathrm{Si}$ & 2.94 & 2.90 & 3.90 & 3.90 \\
${ }^{\mathrm{IV}} \mathrm{Al}$ & 1.06 & 1.10 & 0.10 & 0.10 \\
${ }^{\mathrm{VI}} \mathrm{Al}$ & 1.92 & 1.88 & 4.01 & 4.02 \\
$\mathrm{Ti}^{4+}$ & 0.02 & 0.03 & 0.00 & 0.00 \\
$\mathrm{Mg}^{2+}$ & 0.00 & 0.17 & 0.00 & 0.00 \\
$\mathrm{Fe}^{2+}$ & 0.05 & 0.06 & 0.02 & 0.01 \\
$\mathrm{Na}$ & 0.14 & 0.00 & 0.00 & 0.00 \\
$\mathrm{~K}$ & 0.76 & 0.85 & 0.00 & 0.00 \\
\hline
\end{tabular}

${ }^{1}$ Normalization is based on total anionic charge of 22 .

${ }^{2}$ Normalization is based on total anionic charge of 28 .

tween kaolinite and $\mathrm{Fe}$ oxides at a scale finer than can be resolved by the standard microprobe analysis. Therefore, AEM data for Fe probably represent the maximum contents of this element allowed in this authigenic kaolinite.

\section{Timing of muscovite-kaolinite intergrowths}

The SEM images show that muscovite-kaolinite intergrowths expand into and occlude intergranular porespace (Figure $4 \mathrm{c}$ ). This may suggest that alteration took place before the substantial reduction of primary porosity due to processes of compaction and/or cementation. Nonetheless, these sandstones do not show a significant degree of compaction, and primary porosity has remained throughout their burial history. Moreover, as commented below, microstructural evidence does not support an early origin for kaolinitization.

In most cases, the displacive growth of kaolinite has led to the deformation, to a different extent, of the
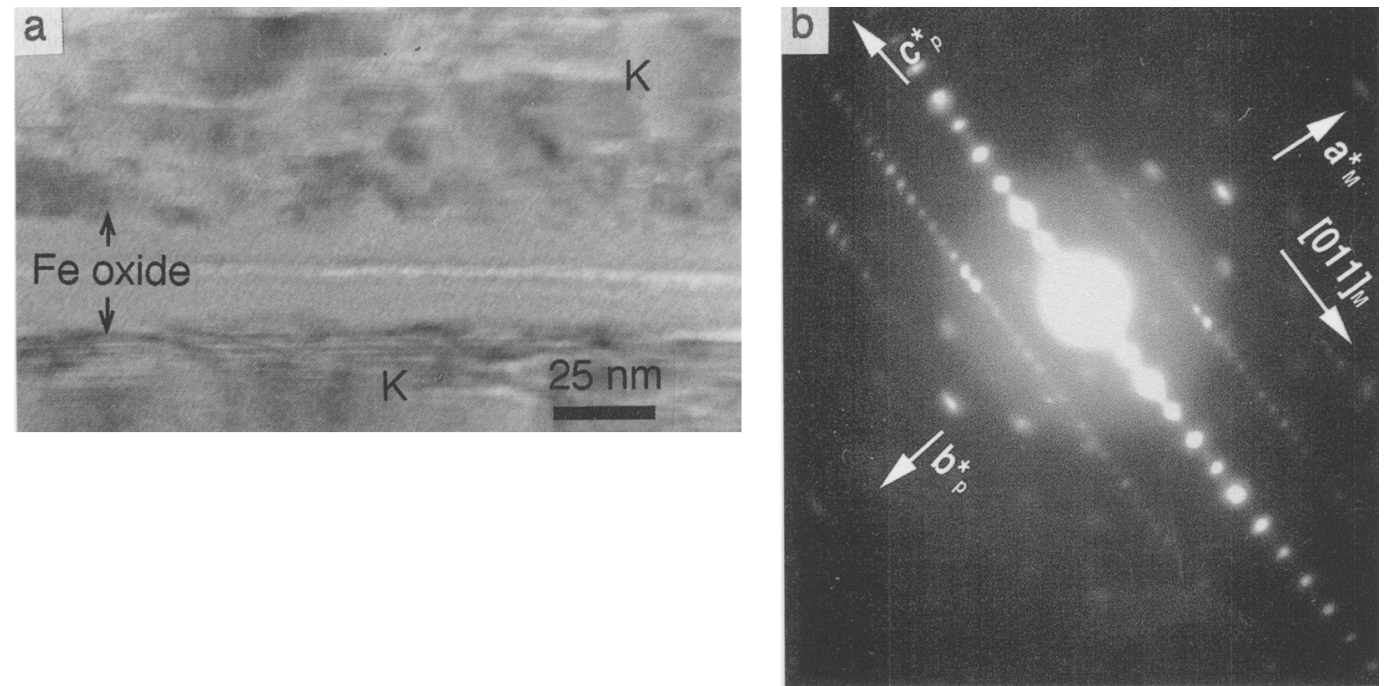

Figure 9. (a) Detail of a $250 \AA$ thick packet of Fe oxide within a kaolinite area. (b) Corresponding electron diffraction pattern showing the crystallographic relations (marked by arrows) between phyllosilicates $\left(\mathbf{b}_{\mathrm{p}}^{*} \mathbf{c}_{\mathrm{p}}^{*}\right.$ ) and Fe oxide $\left(\mathbf{a}^{*}{ }_{\mathrm{m}} 011_{\mathrm{m}}\right)$. 
original grains of detrital muscovite (Figure 4c). However, some of them show evidence of deformation prior to kaolinitization. Figure $4 \mathrm{a}, \mathrm{b}$ shows a deformed grain of mica, where shear stress resulted in the sliding of packets of muscovite and the formation of 'stepshaped' irregularities along the grain edges. Growth of authigenic kaolinite progressed along the previous microfractures. The maximum burial depth for the Utrillas Formation $(700 \mathrm{~m}$, Sanguiesa and Arostegui, 2000 ) indicates a maximum confining pressure of $\sim 18$ $\mathrm{MPa}$, while the shear modulus of muscovite at room temperature is $35.3 \mathrm{GPa}$ (Bass, 1995). Under these conditions, the calculated value $(\sigma=\mathrm{G} \gamma$ ) for the mechanical response associated with deformation of muscovite is negligible $(0.05 \%)$. Thus, the deformation features observed in Figure $4 \mathrm{a}$ (and the subsequent growth of kaolinite) cannot be related to mechanical compaction and burial diagenetic processes.

At confining pressures $<50 \mathrm{MPa}$, the dominant deformation mechanism for muscovite is frictional sliding on (001) (Mares and Kronenberg, 1993). At $400^{\circ} \mathrm{C}$ and confining pressures of 30-40 $\mathrm{MPa}$, deformations $>5 \%$ are obtained. However, at lower temperatures $\left(<100^{\circ} \mathrm{C}\right)$, confining pressures of $60-80 \mathrm{MPa}$ are necessary to obtain similar features. Conditions consistent with this kind of deformation could only be achieved during the uplift of the studied materials as a result of the Alpine orogeny. The Cenomanian limestones on the top of the Utrillas Formation show clear evidence of brecciation, and minimum differential stress of $40 \mathrm{MPa}$ is needed for this process to occur (Lockner, 1995). Therefore, tectonic stress during the Alpine uplift was at least $58 \mathrm{MPa}$, sufficiently high to cause the shear microfractures observed in Figure 4a, b. Moreover, during this stage, sediments were located near the surface, favoring the circulation of meteoric waters.

Figure $4 \mathrm{~d}$ shows a folded and partially broken grain of muscovite. Kaolinitization is clearly post-kinematic, because of the differential growth of kaolinite at both sides of the grain. The temperature and pressure conditions developed through the geological history of the Utrillas Formation did not allow the ductile deformation of muscovite, because this mineral behaves in a ductile fashion at temperatures well above $250^{\circ} \mathrm{C}$ (Paschier and Trouw, 1996). Therefore, the fold observed, prior to grain fracture, should be inherited from the source area.

\section{ACKNOWLEDGMENTS}

This work was supported by the projects PB95-0343-A and BTE2000-0582 (DGI, Spanish Ministry of Science and Technology) and Research Group RNM-0179 of the Junta de Andalucía. We are grateful to Miguel Angel Fernández and María del Mar Abad for their assistance in using the EPMA at the University of Oviedo (Spain) and the HRTEM at the CIC of Granada University (Spain) respectively. We also would like to thank A.R. Mermut and another anonymous reviewer for their helpful comments and suggestions.

\section{REFERENCES}

Bailey, S.W. (1980) Structures of layer silicates. Pp. 1-124 in: Crystal Structures of Clay Minerals and their $X$-ray Identification (G.W. Brindley and G. Brown, editors). Monograph, 5. Mineralogical Society, London.

Banfield, J.F. and Eggleton, R.A. (1990) Analytical transmission electron microscope studies of plagioclase, muscovite and $\mathbf{K}$-feldspar weathering. Clays and Clay Minerals, 38, 77-89.

Bass, J.D. (1995) Elasticity of minerals, glasses and melts. Pp. 45-63 in: Mineral Physics and Crystallography: $A$ Handbook of Physical Constants (T.J. Ahrens, editor). American Geophysical Union Reference Shelf, 2.

Bjørlykke, K. (1998) Clay mineral diagenesis in sedimentary basins - a key to the prediction of rock properties. Example from the North Sea Basin. Clay Minerals, 33, 15-34.

Bjørlykke, K., Malm, O. and Elverhoin, A. (1979) Diagenesis in Mesozoic sandstones from Spitsbergen and the North Sea-a comparison. Geologische Rundschau, 68, 11511171.

Buseck, P.R. (1992) Principles of transmission electron microscopy. Pp. 1-36 in: Minerals and Reactions at the Atomic Sscale: Transmission Electron Microscopy (P.R. Buseck, editor). Reviews in Mineralogy, 27. Mineralogical Society of America, Washington, D.C.

Buseck, P.R., Cowley, J.M. and Eyring, L. (1988) High-Resolution Transmission Electron Microscopy and Associated Techniques. Oxford University Press, New York, pp. 1128.

Champness, P.E., Cliff, G. and Lorimer, G.W. (1981) Quantitative analytical electron microscopy. Bulletin of Mineralogy, 104, 236-240.

Cliff, G. and Lorimer, G.W. (1975) The quantitative analysis of thin specimens. Journal of Microscopy, 103, 203-207.

Craw, D., Coombs, D.S. and Kawachi, Y. (1982) Inter-layered biotite-kaolin and other altered biotites, and their relevance to the biotite isograd in eastern Otago, New Zealand. Mineralogical Magazine, 45, 79-85.

Crowley, S.F (1991) Diagenetic modification of detrital muscovite: an example from the Great Limestone Cyclotherm (Carboniferous) of Co. Durham, UK. Clay Minerals, 26, 91-103.

Jeong, G.Y. (1998) Vermicular kaolinite epitactic on primary phyllosilicates in the weathering profiles of anorthosite. Clays and Clay Minerals, 46, 509-520.

Jiang, W. and Peacor, D.R. (1991) Transmission electron microscopic study of the kaolinitization of muscovite. Clays and Clay Minerals, 39, 1-13.

Jiang, W., Peacor, D.R. and Essene, E. (1994) Clay minerals in the McAdams sandstone, California: implications for substitution of $\mathrm{H}_{3} \mathrm{O}^{+}$and $\mathrm{H}_{2} \mathrm{O}$ and metastability of illite. Clays and Clay Minerals, 42, 35-45.

Kübler, B. (1984) Les indicateurs des transformations physiques et chimiques dans la diagenèse, temperature et calorimetric. Pp. 489-596 in: Themométrie et Barometrie Géologiques (M. Lagache, editor). Societé Française de Mineralogie et Cristallographie, Paris.

Lockner, D.A. (1995) Rock failure. Pp. 127-147 in: Rock Physics and Phase Relations: A Handbook of Physical Constants (T.J. Ahrens, editor). American Geophysical Union Reference Shelf, 3.

Ma, C. and Eggleton, R.A. (1999) Surface layer types of kaolinite: a high-resolution transmission electron microscope study, Clays and Clay Minerals, 47, 181-191.

Mares, V.M. and Kronenberg, A.K. (1993) Experimental deformation in muscovite. Journal of Structural Geology, 15, 1061-1075. 
Marfil, R. and Gomez Gras, D. (1992) Procedencia y modelo diagenético de las areniscas de la facies Utrillas en la Cordillera Ibérica (Umbral de Ateca) y la Meseta norcastellana. Revista de la Sociedad Geológica de España, 5 (3-4), 101-115.

Passchier, C.W. and Trouw, R.A.J. (1996) Microtectonics. Springer, Berlin, 289 pp.

Rat, P. (1988) The Basque-Cantabrian basin between the Iberian and European plates: some facts but many problems. Revista de la Sociedad Geológica España, 1, 327-348.

Robertson, I.D.M. and Eggleton, R.A. (1991) Weathering of granitic muscovite to kaolinite and halloysite and of plagioclase-derived kaolinite to halloysite. Clays and Clay Minerals, 39, 113-126.

Sangüesa, FJ. and Arostegui, J. (2000) Modelo subsidente y térmico. Naturaleza, origen y distribución de los yacimien- tos de ambar de Peñacerrada (Álava-Spain). Museo de Ciencias Naturales de Álava, Spain, $22 \mathrm{pp}$.

Singh, B. and Gilkes, R.J. (1991) Weathering of a chromian muscovite to kaolinite. Clays and Clay Minerals, 39, 571579.

Zuluaga, M.C., Irabien, M.J., Sangüesa, F.J., Aranburu, A., Agirrezabala, L.M. and Arostegui, J. (1998) Clay mineralogy of Albian sediments in a type section (San Felices) from the southern border of the Basque-Cantabrian basin (northern Spain). Proceedings $2^{\text {nd }}$ Mediterranean Clay Meeting, Aveiro, Portugal, pp. 102-107.

E-mail of corresponding author: nppargaj@Ig.ehu.es (Received 13 May 2000; revised 2 April 2001; Ms 450; A.E. Peter J. Heaney) 